\title{
QR Code-based Learning Development: Accessing Math Game for Children Learning Enhancement
}

\author{
https://doi.org/10.3991/ijim.v13i11.10976
}

\author{
Widyasari Widyasari $\left.{ }^{(}\right)$, Hadi Sutopo, Murniati Agustian \\ Universitas Djuanda, Bogor, Indonesia \\ widyasari@unida.ac.id
}

\begin{abstract}
Mathematics in primary school is difficult to understand, boring, formal, theoretical, and book-based learning, which makes students tired of listening and paying attention. The purpose of this study is to create a learning prototype based on $\mathrm{QR}$ codes, especially mathematics learning in primary schools. Using the QR code, students can access math games related to the course. This learning model could encourage students to learn mathematics. The research included seven steps in research and development named after Borg \& Gall, such as need assessment, plan, early product development, first test, revise early product, field test and revise product. The object of the research is QR code-based learning, and the respondents are primary school students and teachers. After analyzing data in the first and field test, researchers found the result. QR code-based learning could support children for learning mathematics.
\end{abstract}

Keywords-Mathematics; learning; QR code; web address; smartphone

\section{Introduction}

Semiawan said that learning is important for everyone in the whole life. People learns, and they can get the knowledge and skills to adapt many changes in environment [1]. In primary school, learning mathematics formally and theoretically, as well as learning from books [2]. The subject of mathematics is not fun for them, because it is a hard subject that children cannot learn in an interesting situation. Children learn mathematics in school that falls into some part of subject, for examples numbers, geometry, and shape [3]. Students consider that it is not easy to understand mathematics. While teachers try to make students understand mathematics, but their effort does not succeed easily [4]. Because math is a difficult topic for many children, playing game is fun and supports to learn math. These tips for playing with math in primary school is worth to be done.

The huge development of information and communication technologies (ICT) changed the lifestyles, including the method of learning. There are many methods of learning using ICT, i.e. computer-assisted learning, e-learning, distance education, and others, that can be accessed using tablet and PC [5]. The implementation of computer-assisted learning in the process of learning using multimedia increases student creativity and innovation [6]. Multimedia means integration of word, pictures, 
audio, and video played through a computer or digital devices [7]. By combining the multimedia elements such as text with pictures, animations with audio, text and video, those in need of it can gain a clear meaning. Vaughan said that multimedia make the learning process changes, from teacher-center to student-center learning. When information technology is used to facilitate students with new teaching methods, it can enhance the meaning of content to be understood. Students can find all information easily, using pictures, sound and text to convey the learning material they have got in class. Dynamic development of mobile devices increase technology for designing mobile application [8]. Using mobile technologies educator can display science in natural environment. Mobile phones are used increasingly in schools, at home, and anywhere, that makes information technology is used increasingly. Children are born in the surrounding technologies and can use the mobile phone independently. The disadvantage is accessing to many movies, games that are not worth for children [9]. Teachers should think about creating an interesting model of learning that is used to play by children.

\subsection{Millennials generation}

Youth profiles change over time, and the nature of the care and commitment of the community deviates. However, teachers teaching in schools and universities are almost the same, with little attention being paid to generations of youth [10]. How young people learn depends on their opportunities and their well-being in the future. That is why it is important to identify each generation in the way they process the world around them, how they work together with authority, how it affects families and communities, and what to do to improve their chances maximize their goals. A number of concepts have been put together to find teaching options with different and complex influences in the learning process of 21 st century students. The student generation is divided into three generations, such as Generation X (1965-1985); Generation Y (1978-2000), also known as Millennium; and Generation Z (1995-2012) [11].

An interesting mathematics learning can be made for primary and middle school. The teacher will give students the web address they can access. Then students enter the web address on their smartphone. The teacher does not do everything as far as possible to automate the students and take responsibility, but teacher wants to be learning facilitators. Smartphones are a kind of devices used by most young people and have really become an extension of their hands [12]. It is not easy to write long characters in a web address, because sometimes typing errors occur. Accessing the subject can easily be done via QR codes.

\subsection{QR code}

There are several reasons in using a QR code. The main reason, however, is that it is easy to give students web addresses and allow them to be more independent. QR codes reduce the frustration of students entering web addresses. Although they can use shorter links, even seven-year-olds find it is difficult to get the right touch. With a 
QR code, students can save time without typing, and students will get it right the first time. It is rare for students to enter the web address incorrectly on their smartphones. [13].

Using computer-aided learning provided with multimedia become widespread in schools, and is adapting into the mobile environment. Children are born while the mobile phones are used by people, so children can learn quickly to use them [14]. QR codes have the popularity of classic barcodes in many areas due to numerous benefits such as increasing capacity, reducing size, etc. Combining with the variety and enhancement offered, the use of QR codes makes it more attractive than barcodes. QR codes can symbolize the same amount of data by one-tenth of the conventional barcode.

The advantages of QR code over traditional barcode as can be seen in Table 1, are described as follow:

- If not a QR code, the only way to connect students to online content is using a URL. A barcode cannot be used to access an online content [15]

- With QR codes, students can get a way to access unlimited information

- A QR code holds hundreds of times more information than a barcode. QR is a twodimensional barcode widely used for many purposes

- Using QR codes, students can link to multimedia content of learning, as text, image or video

- When scanned, the QR code redirects the students to many information that present as text, image, or video. While a barcode as visual representation of machinereadable information about the product to which it's attached. To put it down for a layman, a barcode is that small box printed on the packaging of a product, that has a small collection of black parallel lines of varying widths [15]. A barcode only stores information such as type, size, factory, number of product and country of origin [16]

- A QR code can be scanned using a smartphone [14], while a barcode can only be read by a dedicated barcode reader machine

- Codes that are found in magazines, brochures, store shelves, and billboards can be scanned using phone's camera at a long distance, while a barcode is usually scanned at a short distance [17].

Table 1. Advantages QR Code over Traditional Barcode

\begin{tabular}{|l|l|l|l|}
\hline & & \multicolumn{1}{|c|}{ QR code } & \multicolumn{1}{c|}{ Barcode } \\
\hline 1 & Connect to web page & Yes & No \\
\hline 2 & Access information & Unlimited & Limited \\
\hline 3 & Using purpose & Many & Product information \\
\hline 4 & Access to multimedia object & Yes & No \\
\hline 5 & Get product information & Yes & Yes \\
\hline 6 & Device to scan & Mobile phone & Bar code reader \\
\hline 7 & Distance where it is scanned & At a distance & Near \\
\hline
\end{tabular}




\section{Research Method}

Research and Development (R\&D) according to Borg and Gall [18][19] uses in this research, as can be seen in Figure 1, which consists of ten stages:

- Need Assessment

- Plan

- Early Product Development

- First Test

- Revise of Early Product

- Field Test

- Revise Product

- Operational Test

- Revise Final Product

- Implementation

This research only involved seven stages, according to the requirements of the course material in primary school. These include:

- Need Analyzing: In this stage the information of learning is collected, and searching literature

- Planning: Now that researchers have the information needed, plan to build an application

- Early Product Development: After creating a plan, the next stage is to develop early product. Reviews and suggestions from colleagues in fields of education, visual communication design and computer science are needed

- First Test: The first reviews of experts are carried out after the product developed was fully related to education, visual communication design, and computer science

- Revise Early Product: After conducting the first test, the product is revised in the next stage according to the comment of respondents

- Field Testing: After revising the original product, a field test is conducted to evaluate the product. Students and teachers fill the questionnaires to give feedback. During the test stage, interviews will be conducted with several students and teachers

- Revise Operational Product: After conducting field test, the next stage is revising the product based on the feedback in Field Test. 


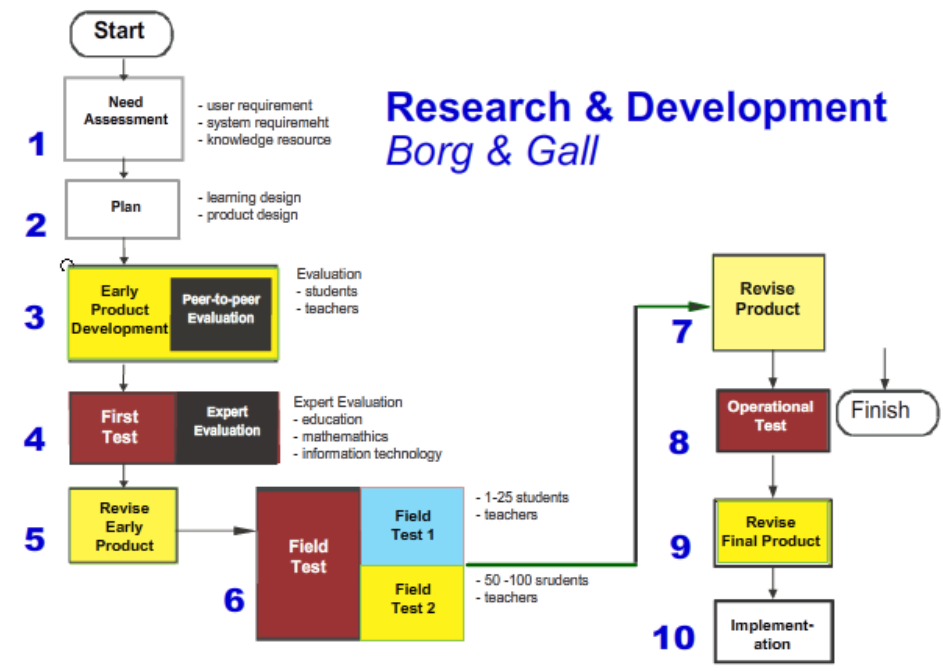

Fig. 1. Model of Research and Development according Borg and Gall [11]

The research subject is mathematical applications, especially mobile games, and the location of the study is a primary school in Jakarta, Indonesia. Respondents consists of children who study in the school and experts in the fields of education, visual communication design and computer science.

\section{Results and Discussion}

\subsection{Need assessment}

The object of the research was QR code-based learning, and the research was conducted in a primary school in Jakarta with students and teachers as the respondents. Analyzing and processing data carried out with seven stages including need assessment, plan, early product development, first test, revise early product, field test and revise product [18].

The goal of this stage is to get information that students and teachers need to develop QR code-based learning. The research was conducted at a primary school in Jakarta, Indonesia, where children and teachers participated. Data of the research were collected from the instruments with details: (1) Open-ended questionnaires were used to find useful information to support the theory, information needed for system development, information about what kind of system to be developed; and (2) Openended interviews were used, then the respondents gave answers that was not restricted from a general point of view. In addition, extensive interviews were conducted to get data on the math learning. The following questionnaires were distributed to the respondents.

Questionnaires used in the first stage: 
- If you compare digital learning resources with book learning resources, can you explain which ones are interesting and easy to use?

- How do you find other sources for learning mathematics? There are many methods such as in classrooms, in groups, in libraries or on the internet.

- People need interactive media through smartphones, play augmented reality, and play games, but some people still like reading books. How about you?

- Which math topics are difficult for you to understand?

- Which math topics are interested for you?

Data that were collected by students and teachers, were processed using software for qualitative data processing. As a result of answering the questions above, the majority of respondents gave the following statement as follows.

Need assessment results:

- Most of the respondents liked internet and social media more than book and printed media.

- Most respondents found mathematics resources from internet.

- Most of respondents used smartphones for everyday activities, getting information and enhancing their knowledge.

- Almost all respondents agreed that fractions and geometry would be the most difficult to understand.

- Many respondents were fond of number and measurement.

Multi-step analysis and data processing involves collect data, prepare data, read intention, create code, display data, and analyze data [20].

The audience's goals and desired influence the style of the application. Based on research findings after discussions with students and teachers, QR code-based learning were described in Table 2, about users, modules consisting of several topics, and applications that explain how and what types of devices were used.

Table 2. The concept of $\mathrm{QR}$ Code-based and competency learning

\begin{tabular}{|l|l|}
\hline \multicolumn{1}{|c|}{ Object } & \multicolumn{1}{c|}{ Description } \\
\hline User & Primary school students and teachers \\
\hline Module & $\begin{array}{l}\text { Module: } \\
\text { Topics of learning } \\
\text { Source of learning } \\
\text { Competency gain on learning } \\
\text { Process of learning } \\
\text { Evaluation of learning }\end{array}$ \\
\hline CR code & QR code is printed on a book page that links to learning resource \\
\hline
\end{tabular}




\subsection{Plan}

After the Need Assessment stage had been conducted, the next stage was Plan with creating design that consisted of instructional design, conceptual design and book design.

Instructional Design: Organization of learning how the instruction was developed. This process included deciding objectives of learning, the best of the learning methods, and action for guidance of the learning. Learning methods included classroom learning. Table 3 shows the instructional design.

At this stage, the learning organization was made as a master plan for providing instructions. This process involved choosing the optimal teaching method and creating useful subject of learning, action-oriented and focused learning goals that guide learning. Possible teaching methods included classroom learning.

Table 3. Instructional design

\begin{tabular}{|c|c|}
\hline Object & Description \\
\hline Course Id & MA-01 \\
\hline Title & Fundamental of Mathematics \\
\hline Duration & 48 hours \\
\hline Module & \begin{tabular}{|ll} 
Module: & \\
1. & Introduction \\
2. & Number \\
3. & Shape \\
4. & Geometry \\
5. & Fractions \\
\end{tabular} \\
\hline CR code & QR code is printed on a book page that links to a math game \\
\hline Description & $\begin{array}{l}\text { During the learning in class, teacher asks students to access a math game in } \\
\text { website by scanning a QR code that is printed in the book using their } \\
\text { smartphones. }\end{array}$ \\
\hline
\end{tabular}

Conceptual Design: The first step was creating Course outline, as part of learning, that was the first display of a learning. The learning was divided into three subjects as Course Outline, Course Plan, and Assignment. In Course Outline, user could find information about course title, duration of course, teacher identity, and name of teacher. Teacher could see the teaching schedule and entry the score of students, and download the instruction guide.

Learning resources must be accessed via a smartphone as needed by the user [21]. The design of the learning course integrated into the design of $\mathrm{QR}$ codes. This concept was the concept of application development and must be considered in all aspects. Creating a design must be considered a simple and generic design. Design described application functionality and methods such as the relationship between learning objects, QR codes and learning source URLs, as can be seen in Figure 2. Functional design could reduce the possibility of implementation errors. 

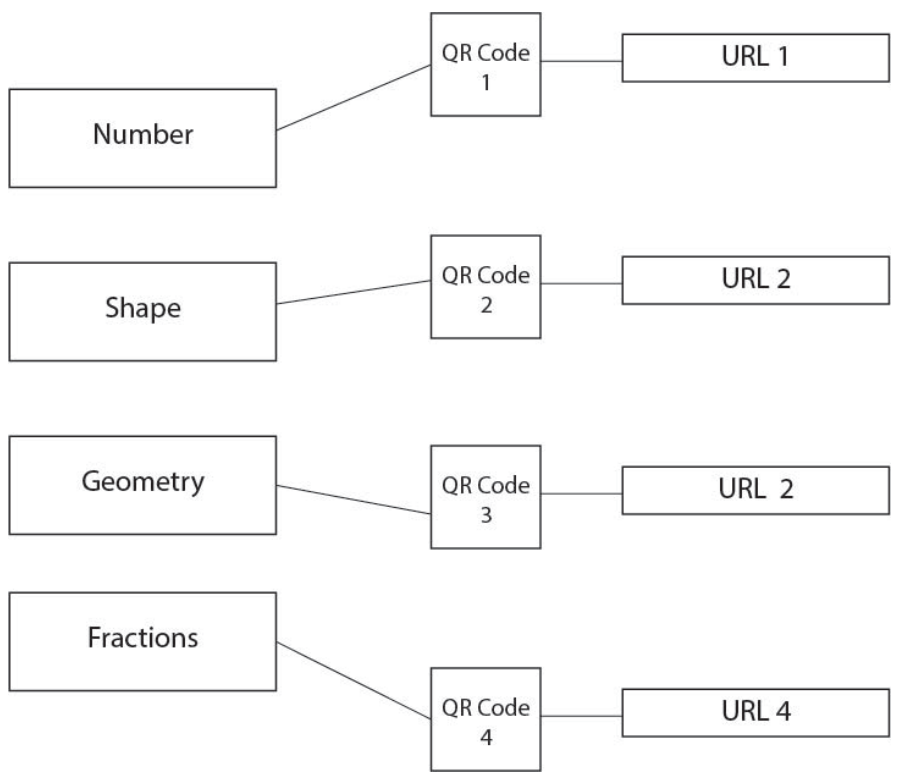

Fig. 2. Relationship between the subjects, the QR code, and URLs

Book Design: Book design consists of three book parts, are front matter, main matter and back matter. Design of front matter included France title, Book title, Copyright page, Preface and Table of content, while main matter included the main content of the subject of the book, and back matter consisted of index, and word lists. [22]. Figure 3 shows the book design that guided developing the instructional content to be a good book. After the design stage had been conducted, the next stage was development that consisted of development of instructional content, resource learning, and QR code. 


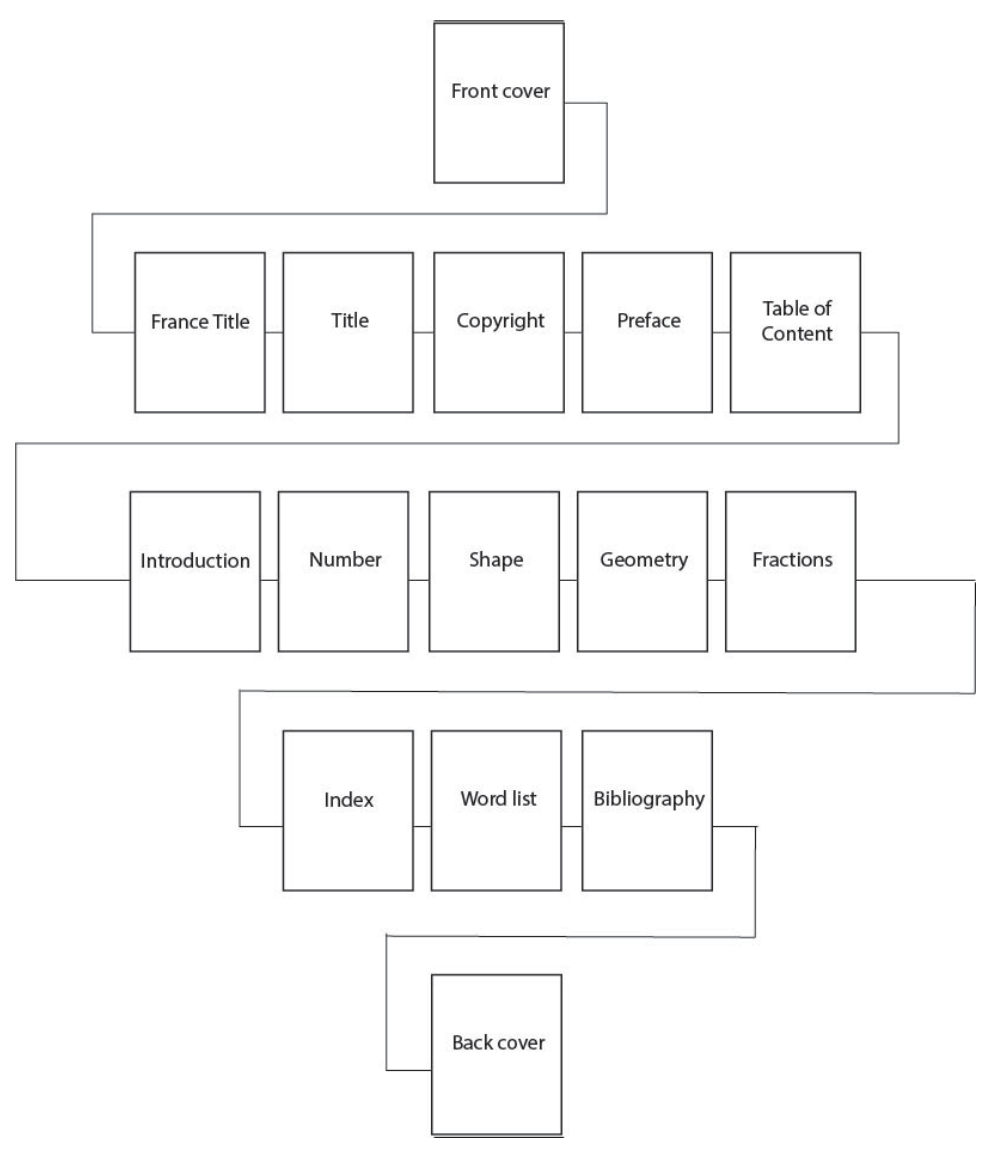

Fig. 3. Book design of math instructional design

\subsection{Early Product}

After the Plan stage had been conducted, the next stage was Early Product with creating book of math instruction, resource learning and qr code.

Instruction Content: The first step was creating Course outline as the first display of a learning. The learning outline consisted of Course Outline, Course Plan, and Assignment subject. In Course Outline, user could find information about course title, duration of course, teacher identity, and name of teacher. Teacher could see the teaching schedule and entry the score of students, and download the instruction guide. Figure 4 shows Course Plan, that identified competency, topic, learning method, duration, and references. 


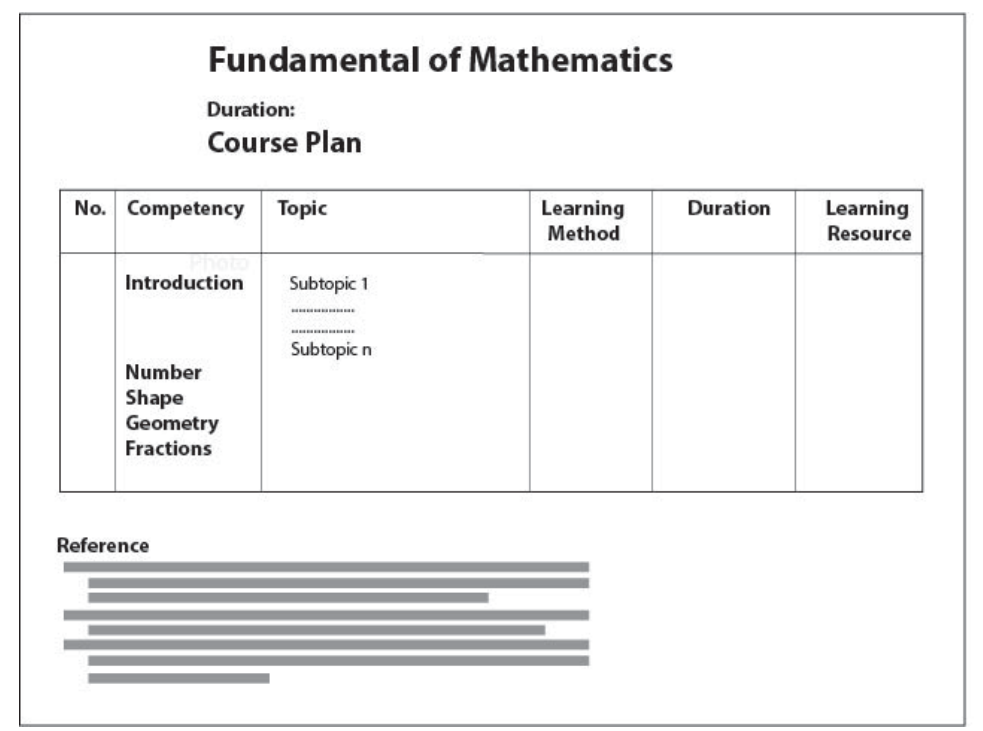

Fig. 4. Figure 4 Course plan

Resource Learning: In this stage, learning resources from various formats such as text, images, sounds, and animations were created or collected. This study used mobile games as a learning resource [19]. It can be one or more of the multimedia elements that was could make a clear meaning. Students can find information, use pictures, sounds and texts to communicate what they have learned. The growth of mobile devices made possibilities for people to reach many information using mobile phones [23].

QR Code: However, as shown in Figure 2, QR codes have many advantages over traditional bar codes [15][16]; The main advantage is that up to one hundred times more information can be stored in a QR code than on a standard horizontal bar code . Another major advantage is that the appearance of the code is unique and interesting from a marketing perspective, which increases the likelihood that customers will be involved in any campaign where the code is used. [14].

There are many websites where instructional designers can produce QR codes, and most of them are free. The researcher can then download it to print on the computer. Google search for "QR code makers" leads to countless results with different options. So this is just about choosing an option that works well [14]. QR code readers can be downloaded by anyone to smartphone, and most of them are free. This means that each student can scan the QR code with smartphone. Android users can use a QR code reader, and iPhone users can download the Quick Scan application.

\subsection{Testing}

Through the development of QR code-based learning methods, books were provided with printed QR codes. During the study, the teacher asked students to open 
the book page on which the CR code was printed. Students first scanned the QR code to access the mathematics game on the Web site, as can be seen in Figure 5. Once the QR code had been tested, the entire game and the book must be tested by students and teachers.

The math game could be accessed by students anytime and anywhere, so they could remind the math knowledge that teachers delivered in class. Many kinds of math game can be created as learning resources, and of course they can increase students learning outcome using mobile technologies in education [24]. Figure 5 shows the relationship between the subject, the QR code, and the game. Figure 6 shows the math game that can be accessed anytime and anywhere [19].

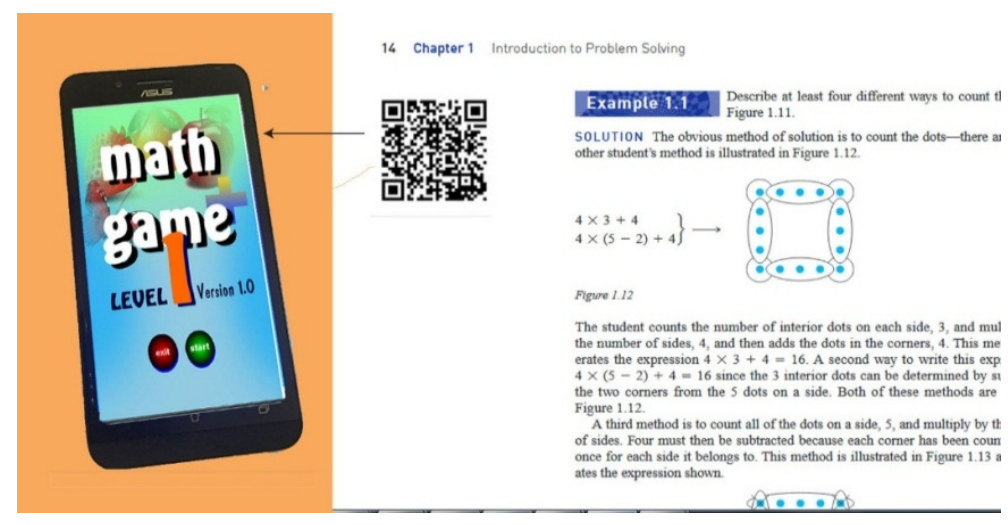

Fig. 5. Relationship between the subject, the QR code, and the game

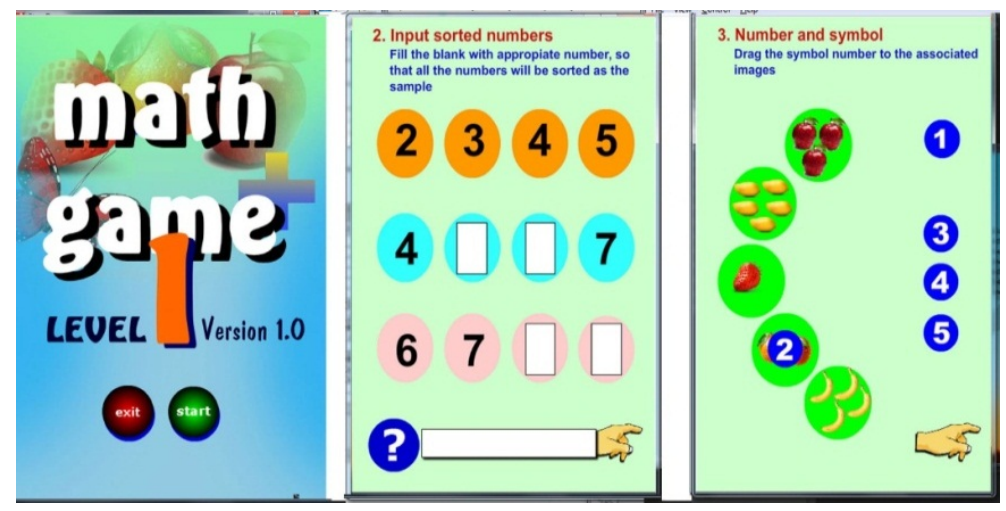

Fig. 6. Math mobile game [19]

\section{$4 \quad$ Research Limitation}

The research was limited in developing prototype of learning, especially QR codebased learning: 
- This study was conducted from first stage to third one in accordance with the needs of creating prototype of QR code-based learning in the particular primary school in Jakarta Indonesia. It should be evaluated by experts in education, mathematics and information technology

- The tested subject was not all the content of math book.

\section{Conclusion}

The results of this research are:

- Need assessment in which students take information needs for QR code-based learning prototypes. The initial investigation information serves as a guide for developing QR code-based learning

- Development of QR code-based learning was conducted and organizes according the Borg and Gall model

- QR code-based learning supported teachers in learning process [25], since it can access a math game, children can be motivated to learn mathematics. The math game as learning resource can be accessed by students anytime and anywhere, so it can increase students learning outcome [26].

The learning model can used be for practice in especially teachers and educational technology developer for learning improvement. The point of future research is continuing the stage of QR code-based learning in operational test, revise final product and implementation. In addition, the $\mathrm{QR}$ code-based learning process must be able to run on any platform, product, and resolution of mobile device.

\section{Acknowledgement}

Authors would like to thank to Djuanda University, Kalbis Institute, and Atma Jaya Catholic University of Indonesia that gave support in the research, and several persons that conducted the survey and data collecting.

\section{$7 \quad$ References}

[1] C. R. Semiawan, Landasan Pembelajaran dalam Perkembangan Manusia. Jakarta: Centre of Human Competency Development, 2007.

[2] S. Papadakis, M. Kalogiannakis, and N. Zaranis, "Improving Mathematics Teaching in Kindergarten with Realistic Mathematical Education,” Early Child. Educ. J., vol. 45, no. 3, pp. 369-378, 2016. https://doi.org/10.1007/s10643-015-0768-4

[3] A. Arumsari, Pelajaran Matematika untuk SD/MI Kelas 3. Bandung: CV Irama Jaya, 2009.

[4] S. Papadakis and M. Kalogiannakis, "Mobile educational applications for children. What educators and parents need to know," Int. J. Mob. Learn. Organ. (Special Issue Mob. Learn. Appl. Strateg., vol. 11, no. 3, pp. 256-277, 2017. https://doi.org/10.1504/ijmlo.2017 .085338 
[5] S. Papadakis, M. Kalogiannakis, and N. Zaranis, "Comparing tablets and PCs in teaching mathematics: An attempt to improve mathematics competence in early childhood education," Presch. Prim. Educ., vol. 4, no. 2, pp. 241-253, 2016. https://doi.org/10.12681/ ppej.8779

[6] S. Papadakis, M. Kalogiannakis, and N. Zaranis, "The effectiveness of computer and tablet assisted intervention in early childhood students' understanding of numbers. An empirical study conducted in Greece,” Educ. Inf. Technol., vol. 23, no. 5, pp. 1849-1871, 2018. https ://doi.org/10.1007/s10639-018-9693-7

[7] T. Vaughan, Multimedia Making It Work. Yogyakarta: Andi Publisher, 2006.

[8] Q. H. Mahmoud and A. Dyer, "Integrating BlackBerry Wireless Devices into Computer Programming and Literacy Courses," in The 45th Annual Southeast Regional Conference (ACM-SE 2007), 2007. https://doi.org/10.1145/1233341.1233430

[9] A. Sulleyman, "The majority of young people sleep with their handset within arm's reach, and check it when they wake up briefly during the night," 2018. [Online]. Available: https://www.independent.co.uk/life-style/gadgets-and-tech/news/millennials-generation-zsmartphone-habits-apps-communications-real-life-a8008641.html. [Accessed: 16-May2018].

[10] J. Grajczonek, “Early Childhood Education.,” J. Relig. Educ., vol. 59, no. 3, p. 3, 2011.

[11] R. Swanzen, "Facing the Generation Chasm: The Parenting and Teaching of Generation Y and Z," Int. J. Child, Youth Fam. Stud., vol. 9, pp. 127-128, 2018.

[12] M. K. Chang and S. Law, "Factor structure for Young's Internet Addiction Test: A confirmatory study," Hum. Behav., vol. 24, no. 6, pp. 2597-2619, 2008.

[13] A. Park, "Cell-Phone Distracted Parenting Can Have Long-Term Consequences: Study," 2018. [Online]. Available: http://time.com/4168688/cell-phone-distracted-parenting-canhave-long-term-consequences-study/. [Accessed: 26-Jul-2018].

[14] H. Kinjal, "A Survey on QR Codes: in context of Research and Application," Int. J. Emerg. Technol. Adv. Eng., vol. 4, no. 3, pp. 258-252, 2014.

[15] A. Ashish, "What's a QR Code And How Is It Different From A Barcode?" [Online]. Available: https://www.scienceabc.com/innovation/whats-qr-code-how-its-different-frombarcode.html.

[16] B. Johnson, "Barcode Education Guide," IDAutomation.com, 2012. [Online]. Available: https://www.idautomation.com/barcode-faq/barcode-educational-guide.pdf.

[17] "Definition of: QR code," PC. [Online]. Available: https://www.pcmag.com/encyclopedia/ term/61424/qr-code. [Accessed: 04-Dec-2018].

[18] M. Gall, W. Borg, and J. P. Gall, Educational Research: An Introduction, 7th ed. Upper Saddle River, NJ: Pearson, 2003.

[19] H. Sutopo, "Mobile Game Developing: Math Mobile Game Learning Model," Int. J. Inf. Electron. Eng., vol. 7, no. 2, pp. 62-67, 2017. https://doi.org/10.18178/ijiee.2017.7.2.662

[20] J. W. Creswell, Educational Research: Planning, Conducting and Evaluating Quantitative and Qualitative Research. Boston: Pearson, 2014.

[21] M. Kalogiannakis, M. Ampartzaki, S. Papadakis, and E. Skaraki, "Teaching Natural Science Concepts to Young Children with Mobile Devices and Hands-on Activities. A Case Study.," Int. J. Teach. Case Stud., vol. 9, no. 2, pp. 171-183, 2018. https://doi.org/10. 1504/ijtcs.2018.090965

[22] A. H. Sutopo, Desain Buku Dengan Adobe InDesign. Jakarta: Elex Media Komputindo.

[23] M. Neil, "What Is a QR code and How Does It Work? Technology Trends 14," 2014. [Online]. Available: https://smallbiztrends.com/2015/05/what-is-a-qr-code.html\%0A\%0A. [Accessed: 02-Feb-2019]. 
[24] S. Papadakis and M. Kalogiannakis, "Combining mobile technologies in environmental education: A Greek case study.," Int. J. Mob. Learn. Organ. (Special Issue Mob. Learn. Appl. Strateg., vol. 11, no. 2, pp. 256-277, 2017.

[25] S. Papadakis and M. Kalogiannakis, "Combining mobile technologies in environmental education: A Greek case study,” Int. J. Mob. Learn. Organ., vol. 11, no. 3, pp. 256-277, 2017.

[26] S. Papadakis, M. Kalogiannakis, and N. Zaranis, "The effectiveness of computer and tablet assisted intervention in early childhood students' understanding of numbers. An empirical study conducted in Greece.," Educ. Inf. Technol., vol. 23, no. 5, pp. 1849-1871, 2018. https://doi.org/10.1007/s10639-018-9693-7

\section{Authors}

Widyasari is one member of the set of the elementary school teacher education faculty Indonesia (HDPGSDI), Chairman of the Ar-Rahman Islamic education foundation, had been a dean at the faculty of teacher training and education (20162018), and currently work as a Director of Learning and Downstreaming at Djuanda University, Bogor. She received a Doctorate of Educational Technology from Jakarta State University. Her research is currently occupied to focus on blended learning. She also the author of some books two of them are Lesson Planning and The Teaching Profession, as well as writing several articles in Journals indexed Scopus. Widya also served as editor in chief of the Journal Didaktika Tauhidi and is currently a reviewer in the Indonesian Journal of Social Science.

Hadi Sutopo is senior member of International Institute of Electrical and Electronics Engineers (IEEE) in 2017, senior member of International Association of Computer Science and Information Technology (IACSIT), and member of Association for Educational Communications and Technology (AECT). He is Dean of Faculty of Creative Industry Kalbis Institute, Indonesia. He has authored many books on multimedia, information technology and educational technology. Many articles in journals and proceedings were published indexed by Scopus. Dr. Hadi Sutopo received a Doctorate of Educational Technology, Master of Management Information Systems and Bachelor of Informatics. His current research focuses on multimedia, computer graphics, and various aspects of educational technology.

Murniati Agustian is a Graduate from Doctoral Program of Educational Technology, Jakarta State University. Since 1987 she has been working at Catholic University of Atma Jaya, and the first career was as a researcher. With the main scope of work, she is developing the learning media, and conducting some research at the Centre for Community Development Studies (1987-2009). Then she continued her career as a lecturer in Study Program of Elementary School Teacher. She also has written several books, created and designed some audio visual media as tools of the teaching aids.

Article submitted 2019-06-02. Resubmitted 2019-08-07. Final acceptance 2019-08-08. Final version published as submitted by the authors. 